\title{
GENDER POLICY IN INSURANCE COMPANIES IN THE REPUBLIC OF NORTH MACEDONIA
}

\section{Sulejman AHMEDI}

Faculty of Law, University of Tetovo, Street Ilinden bb, Tetovo, Republic of N. Macedonia Correspondence: sulejman.ahmedi@unite.edu.mk, sulejman.ahmedi@aso.mk

\section{ABSTRACT}

The chosen topic in this research „Gender policy in insurance companies in the Republic of North Macedonia" is an issue which has not been tackled so far. Therefore, it represents an interesting topic for the insurance companies and for the general public, as well.

Based on the collected data during the research, which included a survey of 16 insurance companies from which 11 apply non-life and 5 apply life insurance activities, the given answers generally show that women are represented adequately and managerial positions like for ex. head of department or head of directorate are generally led by women. As it can be seen from the title of the topic, the research is limited only to the insurance area.

Insurance companies are focused on professionalism and the competences/personal qualifications of the employees, yet at the same time giving special importance and priority to the equitable gender representation

The results show that the insurance companies respect the principles of equitable gender representation.

KEYWORDS: insurance companies, gender equality, principles, equitable gender representation, professionalism.

JEL CLASSIFICATION: G22, G29, J16 


\section{INTRODUCTION}

Gender equality, as well as protection from discrimination, are topics ensured by the highest legal act in the country - the Constitution of the Republic of North Macedonia. Legal requirements arising from local legislation, namely the provisions from the Labour Relations Act, the Law on Equal Opportunities for Women and Men, the Law on Prevention and Protection Against Discrimination, as well as applicable international conventions in North Macedonia and other laws, regulate the complex issues about gender policies.

This research intends to offer an overview of the current situation of gender representation in the insurance sector, namely in local insurance companies.

Insurance company is a joint stock company with headquarters in North Macedonia, which has permission by the Insurance supervision agency for the performance of insurance work (Article 12, Insurance supervision Law, 2020).

Issues addressed in this research report include:

- $\quad$ the number of employees and gender representation,

- level of education of the employees,

- company administration (high level of management) as well as gender representation,

- number of managerial positions (middle level of management) and gender representation,

- the employment process (year 2019-2020) and the way of selecting the employees,

- $\quad$ salaries and benefits from the work.

Equality between men and women (gender equality) refers to the equal rights, responsibilities and opportunities of women and men and girls and boys (Office of the Special Advisor on Gender Issues and Advancement of Women, 2001).

Gender equality is not only a basic human right, but its achievement has enormous socio-economic ramification (UN women, n.d.).

The importance that the Republic of North Macedonia dedicates to gender equality can be seen in the conduct of new laws and the supplementation of existing laws, strategies and action plans such as: the Law on Equal Opportunities for Women and Men, the Law on Prevention and Protection Against Discrimination, National Strategy for Gender Equality, National Action Plan for Gender Equality, various reports on the evaluation 
of the implementation of the Law on Equal Opportunities for Women and Men at central and local level.

Also, in accordance with the Law on Equal Opportunities for Women and Men, Article 23 (Law on equal opportunities of women and men, 2012, 2014), within the Ministry of Labour and Social Policy, a procedure is established to ascertain the unequal treatment of women and men. The procedure is conducted by the representative for equal opportunities for women and men, a person employed as a civil servant in the Ministry of Labour and Social Policy.

The representative for equal opportunities for women and men within his competencies, independently performs the duties and tasks related to the legal protection of gender-discriminated persons and initiating the procedure for determining the unequal treatment of women and men in accordance with the provisions of the Law on Equal Opportunities for Women and Men, cooperates with the competent bodies (competent inspection body, Ombudsman or other competent body), prepares annual reports and analyses and performs other activities (Article 21, Law on equal opportunities of women and men, 2012, 2014).

Given the fact that the topic of gender representation in public institutions is an issue addressed and monitored by various local organizations, the purpose of this research is to provide a realistic picture of the state of gender representation in insurance companies.

\subsection{The legal framework}

Article 9 of the Constitution of the Republic of North Macedonia (The Constitution of the Republic of North Macedonia, 1991) states that:

"The citizens of the Republic of North Macedonia are equal in freedoms and rights regardless of gender, race, skin colour, national and social background, political and religious conviction, property and social position. The citizens are equal in front of the Constitution and laws."

The Labour Relations Act, in article 6 (The labour relations act, 2020) provides that: "The employer is not allowed to put his worker or the job applicant in an unequal position depending on his ethnicity or race, skin colour, gender, age, health condition, respectively disabilities, religious beliefs, political and others, membership in unions, 
national or social background, family status, property status, sexual orientation or other personal circumstances"

Law on Equal Opportunities for Women and Men, in article 2 paragraph (2) (The law on equal opportunities of women and men, 2012, 2014) provides:

"(2) Creating equal opportunities is a concern for the whole society, hence of all entities in the public and private sector and is the removal of obstacles and the creation of full equality between women and men ".

The purpose of the Law on Prevention and Protection Against Discrimination (Article 2, Law on Prevention and Protection Against Discrimination, 2020), is to secure the principle of equality and prevention and protection from discrimination in the application of human rights.

The National Action Plan for the Implementation of the Law on the Prevention and Protection Against Discrimination (2015-2020) aims to provide specific tasks and activities over a 5-year period, to advance the goals and implementation of the measures, the expected results, as well as the qualitative and quantitative indicators of success.

The 2016-2020 National Equality and Non-Discrimination Strategy is a strategic document of the Government of the Republic of North Macedonia, which defines the goals, measures, indicators and key policy makers in designing the policy for promotion of rights and equal opportunities in various areas of social life, defining as well responsible implementing agencies and all stakeholders in attaining equality and non-discrimination in the Republic of North Macedonia.

The Gender Responsive Budgeting in the Republic of Macedonia (2012-2017) (Ministry of labour and social policy, n.d.) is focused on three strategic areas: 1) introducing a gender perspective in the programs and budgets of the budget beneficiaries at central and local level, 2) improving the legal framework for the inclusion of gender responsive budgeting, and 3) strengthening the institutional mechanisms and capacity building that are required for incorporation of the gender perspective in the creation of policies and programs and related budgets.

The Convention on the Elimination of all Forms of Discrimination Against Women (CEDAW), approved in 1979 by the General Assembly of UN and has been ratified by 190 member countries, among them also North Macedonia in January $18^{\text {th }}, 1994$. 
By accepting the Convention, states commit themselves to undertake a series of measures to end discrimination against women in all forms, including:

- to incorporate the principle of equality of men and women in their legal system, abolish all discriminatory laws and adopt appropriate ones prohibiting discrimination against women;

- to establish tribunals and other public institutions to ensure the effective protection of women against discrimination; and

- to ensure elimination of all acts of discrimination against women by persons, organizations or enterprises (UN Women, n.d.).

The Convention for Equal Payment 1951 (C 100), Article 1, provides:

„(a) the term reward covers ordinary payments, basic or minimal or salary and any additional income paid to the employee directly or indirectly or in cash or in nature by the employer as a result of the employee's employment;

(b) equal pay term for male and female workers for work with the same competencies refers to the amounts of payment determined without discrimination in relation to gender"1.

\section{RESEARCH METHODOLOGY}

The methodology used for the realization of this research has included the survey of the participants of the insurance companies through the completed questionnaire from $16^{2}$ insurance companies from which 11 apply non-life and 5 apply life insurance activities, the review of local legislation which solves the issues addressed in the report, as well as the conventions or applicable international relations in the Republic of North Macedonia.

The used questionnaire includes twenty one questions, whereas the used language is Macedonian language and its Cyrillic alphabet.

\footnotetext{
${ }^{1}$ Article 1, the Convention for equal payment 1951, this instrument is one of the fundamental conventions General Conference of the International Work Organization, after it was called in Geneva by the Governing Body of the International Work Office, who held his thirty-fourth session in June $6^{\text {th }} 1951$ and decided to approve some of the proposals regarding the principle of equal remuneration for men and women, employees with the same qualifications.

${ }^{2}$ One of the surveyed companies did not respond at all
} 
The research methodology that has been used in this research is the descriptive statistical analysis, during the presentation of the data obtained from the research, graph taken from the questionnaire were also used.

Also, this research uses data from State Statistical Office and Gender Equality Index. The recommendations include proposals derived from research findings during the research period.

\subsection{Research questions and hypotheses}

During this research, it is important to use data that come out of the questionnaire to give answers to the following questions:

1. Are the principles of equitable gender representation respected by insurance companies?

2. Is gender a factor which influences taking a certain managerial position?

Because this research was conducted specifically for the insurance industry in North Macedonia, the first objective of the research is to explore gender equality and the research hypotheses are:

H1: Women are represented equally in the insurance companies.

H2: Important managerial positions in insurance companies are led by female representatives.

\section{LITERATURE REVIEW}

The National Equality and Non-Discrimination Strategy 2016-2020 is a strategic document of the Government of the Republic of North Macedonia, which sets those objectives, measures, indicators, key policy makers for the promotion of equal rights and opportunities in different areas of life, responsible actors and all actors in creating equality and non-discrimination in the Republic of North Macedonia.

The research, DISCRIMINATION IN THE REPUBLIC OF NORTH MACEDONIA: Legal staff, challenges and the perception of the basis of discrimination (Nikolovska, 2020), is intended to reflect the state of discrimination in the Republic of North Macedonia, through the retrospective of the constitutional order and the legal staff to the problems related to the repeal of the Law on Prevention and Protection Against Discrimination and the adoption of the new law in October of 2020. 
The research, HOW REGULATORS USE SEX-DISAGGREGATED DATA AND REGTECH TO ENHANCE FINANCIAL INCLUSION, examines the role that financial services regulators can play in efforts to address financial inclusion of women: how they are using, or could use, sex disaggregated data to enhance women's access to and use of financial products and services of the right quality that meet their needs; and how new technologies could help (Toronto Centre, 2021).

The study THE PERSPECTIVES OF WOMEN FROM RURAL AREAS analyses the existing legal framework and policies, explores the range of social exclusion of women in rural areas, starting from the labor market, local public and social life, participation in local decision-making processes, but at the same time expresses theirs needs and challenges (Risteska et. al, 2011).

WOMEN IN RURAL AREAS - MORE OBSTACLES THAN OPPORTUNITIES. The analysis shows where is the Republic of North Macedonia currently located in relation to the formal-legal achievements in the establishment of gender equality, and at the same time, by identifying problems and the challenges that rural women face on a daily basis in the process of realization of certain rights, shows the extent to which existing legal solutions, policies and practices make these women equal access to education, social and health care (Stojanovikj et al., 2011).

\section{ANALYSIS AND DISCUSSION OF RESULTS}

According to the data of the State Statistical Office, in the III quarter of 2021, the active population in the Republic of North Macedonia is 945,158 people, of which 796,681 are employed and 148,477 are unemployed. The activity rate in this period is 56.2 , the employment rate is 47.4 , while the unemployment rate is 15.7 (State statistical office of R. of NorthMacedonia, n.d.)

\subsection{The number of employees and gender representation}

In all surveyed companies the number of employees is as follows:

- $\quad 26.7 \%$ have from 0 to 50 employees;

- $\quad 13.3 \%$ have from 51 to 100 employees;

- $\quad 33.3 \%$ have from 101 to 150 employees;

- $\quad 26.7 \%$ have over 151 employees; 
From the total number of employees, $93.3 \%$ of insurance companies have declared that the percentage of male employees varies from $26 \%$ to $50 \%$, whereas $100 \%$ of insurance companies have declared that the percentage of employed women is from $51 \%$ to $70 \%$.

Referring to the above data, it turns out that most of the employees or more than $51 \%$ in insurance companies are employed women.

\subsection{Level of education of the employees}

Based on data of State Statistical Office, the majority of employed persons, 55.5\% are with 3 and 4 years of secondary education, of which $36.2 \%$ are men and $19.3 \%$ are women. University level education includes university level education, Master's degree and Doctorate (PhD). According to the Labour Force Survey 2017, 24.0\% of the employed persons had completed university level education, of which $11.6 \%$ men and 12.4\% women (State statistical office, 2017).

When asked what percentage of the total number of employed persons have primary level of education, the respondents answered as follows:

- $53.3 \%$ answered that up to $25 \%$ of the employees have primary level of education, whereas $46.7 \%$ have declared that they don't have such employees.

From the above percentages it can be seen that the employees with primary level of education are in small numbers and in some insurance companies they don't appear at all.

When asked what percentage of the total number of employees are with secondary education, the respondents answered as follows:

- $\quad 66.7 \%$ have answered that $26 \%$ to $50 \%$ of the employees have secondary education;

$26.7 \%$ have answered that $0 \%$ to $25 \%$ of the employees have secondary education;

- $\quad 6.7 \%$ have answered that $51 \%$ to $75 \%$ of the employees have secondary education;

When asked what percentage of the total number of employees are with university level of education, the respondents answered as follows:

- $\quad 73.3 \%$ have answered that $51 \%$ to $75 \%$ of the employees have university level of education (Graphics 2); 
- $\quad 20 \%$ have answered that over $75 \%$ of the employees have university level of education (Graphics 2);

- $\quad 6.7 \%$ have answered that $26 \%$ to $50 \%$ of the employees have university level of education (Graph 1).

\section{Graph 1. The percentage of employees with university level of education}

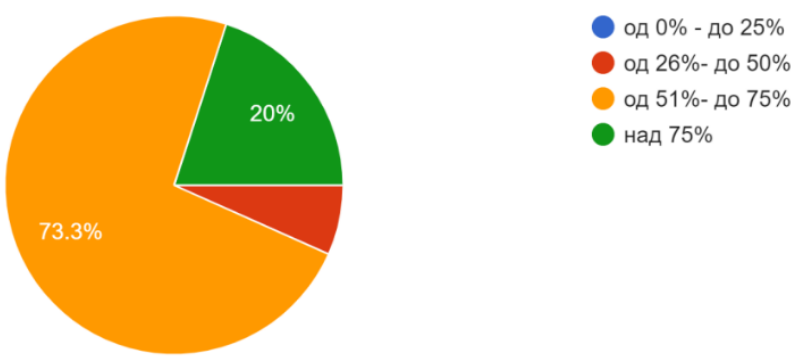

Source: Author

Based on the statements of the respondents, it can be seen that most of the employed persons in the insurance companies have university level of education.

The results show that for insurance companies it is very important that the employed persons have completed university level education.

Based on conclusions of the Gender Equality Index, Women, on average, outperform men in graduates of university education and participation in lifelong learning (UNDPUN Women, 2019).

\subsection{Company administration (high level of management) as well as gender representation}

The corporate administration can be organized according to the single-tier system (Board of Directors) or according to the two-tier system (Managing Board or administrator and Supervisory Board) (Company law, 2014).

When asked how many executive members are in the Board of Directors/members of Managing Board the respondents have answered as it follows:

- $\quad 33.4 \%$ have 1 executive member of the Board of Directors/member of the Managing Board; 
- $\quad 20 \%$ have 2 executive members of the Board of Directors/members of the Managing Board;

$40 \%$ have 3 executive members of the Board of Directors/members of the Managing Board;

- $\quad 6.7 \%$ has 5 executive members of the Board of Directors/members of the Managing Board.

When asked about is the percentage of members of the management body of the company that are female, the respondents answered as follows:

- $\quad 26.6 \%$ don't have female members;

- $\quad 13.3 \%$ have 1 female member;

- $\quad 6.7 \%$ have 3 female members;

- $\quad$ in $20 \%$ of the insurance companies, the percentage of female members is $33.33 \%$

- $\quad$ in $13.3 \%$ of the insurance companies, the percentage of female members is $33 \%$;

- $\quad$ in $6.7 \%$ of the insurance companies, the percentage of female members is $50 \%$;

- $\quad$ in $6.7 \%$ of the insurance companies, the percentage of female members is $100 \%$.

The number of female members in the management bodies varies from company to company, somewhere they are with a higher percentage whereas somewhere the percentage is 0 .

On the question of whether the position of a General Director is currently held by a female-33.3\% answered with „yes“, whereas 66,8\% answered with „no“.

The position of a General Director in most of the insurance companies is held by men, however the percentage of companies that are led by women is not low.

\subsection{Number of managerial positions (middle management) ${ }^{3}$ and gender representation}

When asked about the number of managers in insurance companies, the respondents answered as follows (Table 1):

\footnotetext{
${ }^{3}$ Middle management means any menagerial position in the insurance company (head of department, head of directorate)
} 
Table 1. Number of managers at middle management positions

\begin{tabular}{|c|c|c|}
\hline $\begin{array}{l}\text { Number of } \\
\text { managers }\end{array}$ & $\begin{array}{l}\text { Number of } \\
\text { companies }\end{array}$ & $\begin{array}{c}\text { Number of } \\
\text { companies (\%) }\end{array}$ \\
\hline $1-5$ & 6 & 40 \\
\hline $6-10$ & 5 & 33.33 \\
\hline $11-15$ & 2 & 13.33 \\
\hline $16-20$ & 0 & 0 \\
\hline $21-25$ & 0 & 0 \\
\hline $26-30$ & 2 & 13.33 \\
\hline
\end{tabular}

When asked about the percentage of the total number of managers that belong to women and to men, the respondents answered as follows:

a) $67 \%$ are female $-33 \%$ are men (in $13.33 \%$ of the insurance companies)

b) $27 \%$ are female $-73 \%$ are men (in $26.67 \%$ of the insurance companies)

c) $50 \%$ are female $-50 \%$ are men (in $6.67 \%$ of the companies)

d) $22 \%$ are female $-78 \%$ are men (in $6.67 \%$ of the companies)

e) $100 \%$ are female (in $13.33 \%$ of the insurance companies)

f) $0 \%$ are female $-100 \%$ are men (in $6.67 \%$ of the companies)

g) $43.33 \%$ are female $-56.67 \%$ are men (in $6.67 \%$ of the companies)

h) $54 \%$ are female $-46 \%$ are men (in $6.67 \%$ of the companies)

i) $60 \%$ are female $-40 \%$ are men (in $6.67 \%$ of the companies)

j) $62.5 \%$ are female $-37.5 \%$ are men (in $6.67 \%$ of the companies)

Managerial positions like Head of department and Head of directorate in most of the companies are held by women.

\subsection{Employment (year 2019-2020) and the way of selecting the employees}

To the question whether during 2019 and 2020 there were new employments (and if so, what percentage of them were female), all surveyed companies responded positively, that there were new employments, and the percentage of female employees varied from $34 \%$ to $100 \%$ (60\% in 2 of the companies, $100 \%$ in 2 of the companies, and $62.5 \%, 51,8 \%, 34 \%, 58.49 \%, 63 \%, 65 \%, 67 \%, 47 \%, 76 \%, 50 \%, 90 \%$ in the remaining 11 companies). 
On the question of whether the company uses recruiting strategy to increase the number of female employees, all of the respondents answered with „no“, some of them with the explanation that:

- the company does not need such a strategy and that recruitment is based on the qualifications and experience of the candidates;

- they consider that principles for equitable gender representation are respected

- during the recruitment of staff the appropriate gender representation is taken into account, but also the competencies and professionalism.

The negative answer of the respondents about the strategy for recruitment to increase the number of female employees can be justified because, as it can be seen, even without such a strategy, the principle of gender equality is respected.

When asked whether the company requires a gender-diverse state of candidates for management roles, $67 \%$ of the companies have answered with „no”, while some of them have answered:

- the qualifications of the candidate are crucial;

- while filling managerial positions, the company is more focused on the competencies of the candidates, because according to the structure of gender the relationship is on a solid scale;

- at the moment there is no list of candidates, with the introduction of such a list, attention will be paid to gender equality;

$33.4 \%$ responded positively and one of the companies has responded with "yes", but nevertheless the priority is on the professionalism and the competences of the candidates.

When asked how many of the employees that have left the job during 2020 are female, only one company responded that they didn't have such a case, whilst in other companies the percentage of women employees that have left their job is higher and is $68 \%, 60 \%, 50 \%, 60.9 \%, 29 \%, 46 \%, 52.5 \%, 90 \%, 44.44 \%, 62 \%, 35 \%, 70 \%$, and $36 \%$ per company.

Based on the conclusions of the Gender Equality Index, the duration of the working life of women in the Republic of North Macedonia is, on average, less by 12 years compared to the working life of men which is the second lowest level of average working life of women compared to all other EU member states (UNDP-UN Women, 2019). 
The results obtained for the median tenure (in years) of the company's female and male employees are presented in Tables 2 and 3, respectively.

Table 2. Median tenure (in years) of women employed in the insurance companies

\begin{tabular}{|c|c|c|}
\hline $\begin{array}{l}\text { Median tenure } \\
\text { (in years) }\end{array}$ & $\begin{array}{l}\text { Number of } \\
\text { companies }\end{array}$ & $\begin{array}{c}\text { Number of companies } \\
\qquad(\%)\end{array}$ \\
\hline $1-4$ & 5 & 33.33 \\
\hline $5-8$ & 5 & 33.33 \\
\hline $9-12$ & 2 & 13.33 \\
\hline $\begin{array}{l}\text { Don't have definite } \\
\text { tenure }\end{array}$ & 2 & 13.33 \\
\hline Indefinite tenure & 1 & 6.67 \\
\hline
\end{tabular}

Table 3. Median tenure (in years) of male employed in the insurance companies

\begin{tabular}{|c|c|c|}
\hline $\begin{array}{l}\text { Median tenure } \\
\text { (in years) }\end{array}$ & $\begin{array}{l}\text { Number of } \\
\text { companies }\end{array}$ & $\begin{array}{c}\text { Number of companies } \\
(\%)\end{array}$ \\
\hline $1-4$ & 4 & 26.67 \\
\hline $5-8$ & 6 & 40 \\
\hline $9-12$ & 2 & 13.33 \\
\hline $\begin{array}{l}\text { Don't have definite } \\
\text { tenure }\end{array}$ & 2 & 13.33 \\
\hline Indefinite tenure & 1 & 6.67 \\
\hline
\end{tabular}

\subsection{Salaries and benefits from work}

On the question of whether there is a difference in wages between female and male employees, in $53.6 \%$ there is no difference in salary based on gender; $6.7 \%$ have stated that the difference is plus minus $4 \%$, whilst the remaining half or $40.2 \%$ have stated as follows:

there is a difference in salary only on the basis of the complexity of work; salaries are equal based on job positions; 
- $\quad$ wage difference between employees depends exclusively on the job position and qualifications of the employee;

- $\quad$ salary difference depends on the employment contract.

On the question of whether the company provides benefits $\backslash$ services for family care, $53.6 \%$ answered „no“ whilst 46.8\% answered with „yes“.

On the question of whether flexible working hours are allowed for women returning from maternity leave, most of the respondents in total $80.2 \%$ answered with "yes“, some of them answered as follows:

- $\quad$ yes in certain cases;

- $\quad$ if the job position allows work from home, in agreement with the leader, home office is possible for women returning from maternity leave;

Whilst $13.4 \%$ answered with a „no”, and only $6.7 \%$ answered: - „only if the law allows it".

According to Gender Equality Index for North Macedonia, employed women in North Macedonia have, on average, less flexibility with their working hours compared to men, thus less opportunities to balance between work and private life (UNDP-UN Women, 2019).

In the final question addressed to the respondents - whether you think that the number of employed women is sufficiently represented, all of the respondents have answered with a "yes” even one insurance company answered :- „yes, with increasing tendency“.

\section{CONCLUSION AND RECOMMENDATIONS}

From the research it can be concluded that women are adequately represented in local insurance companies and that female representatives hold managerial positions in company, conclusion by which both hypotheses given at the beginning are verified.

In terms of middle management (head of department, head of directorate), most of them are led by women.

During the last two years (2019 and 2020) new hires mainly involved women employees.

Respondents stated that gender equality is a priority in their companies and that they respect the principles of gender equality. 
It's important to mention that companies, besides the equitable gender representation, consider also the personal competences, level of education and professionalization of the employees.

Gender is not a factor for leading certain positions, but personal qualifications are.

Differences in salaries between the genders do not, salaries are based on the type and the complexity of work.

Given the number of women employed in each insurance company which is $51 \%-70 \%$ it is clearly proved that in this industry women employees do not encounter difficulties during employment.

Recommendations directed to insurance companies:

$>$ In insurance companies which have 1 executive member of the Board of Directors $\backslash$ member of the Managing Board, it is recommended to change the way of administration and to appoint at least 2 executive members of the Board of Directors $\backslash$ members of the Managing Board.

$>$ In insurance companies in which none of the members of the managing bodies are female, it is recommended to give priority to female members.

$>$ It is recommended the number of managerial positions to belong $50 \%$ to women and $50 \%$ to men.

$>$ It is recommended the companies to pay more attention to family care benefits \services

\section{REFERENCES}

- The Constitution of the Republic of North Macedonia. (1991). Official Gazette of Republic of Macedonia, no. 52/1991. Available at: https://www.sobranie.mk/content/Odluki\%20USTAV/UstavSRSM.pdf

○ Convention for equal payment. (1951). Available at: https://kss.mk/wpcontent/uploads/2016/09/100-Konvencija-za-ednakvo-plakjanje-1951.pdf

- Company Law. (2014). Official Gazette of Republic of North Macedonia" no..138/14. Available at: https://aso.mk/wp-content/uploads/2019/04/Zakon-za-trgovskitedrustva.pdf

- Gender Responsive Budgeting in the Republic of Macedonia (2012-2017), Ministry of Labour and Social Policy. Available at: https://www.globalwps.org/data/MKD/files/2012- 
2017\%20Strategy\%20for\%20Introducing\%20Gender\%20Responsive\%20Budgeting

.pdf

- Insurance Supervision Law. (2020). Offical Gazette of the Republic of North Macedonia, no.31/2020. Available at: https://aso.mk/wp-content/uploads/2020/02/zsoneoficijalen-precisten-31-2020.pdf

- Labour Relations Act of Republic of North Macedonia. (2020). Official Gazette of the Republic of North Macedonia, no.267/20. Available at: https://www.mtsp.gov.mk/content/pdf/trud 2017/pravilnici/16,11\%D0\%B0\%D0\%BA\%D0\%BE\%D0\%BD\%D0\%A0\%D0\%B0\%D0\%B1\%D0\%9E\%D0\% B4\%D0\%BD\%D0\%BE\%D1\%81\%D0\%B8.pdf

- Law on Equal Opportunities of Women and Men of Republic of North Macedonia. (2012, 2014). Official Gazette of the Republic of Macedonia, 6/2012, 166/2014). Available at: https://www.mtsp.gov.mk/content/pdf/zakoni/2017/precisten\%20tekst\%202015 \%20na\%20ZEM nov.pdf

- Law on Prevention and Protection Against Discrimination of Republic of North Macedonia. (2020). Official Gazette of Republic of North Macedonia, no.. 258/2020. Available at: https://www.mtsp.gov.mk/content/\%D0\%97\%D0\%B0\%D0\%BA\%D0\%BE\%D0\%B D\%20\%D0\%B7\%D0\%B0\%20\%D1\%81\%D0\%BF\%D1\%80\%D0\%B5\%D1\%87\%D1 \%83\%D0\%B2\%D0\%B0\%D1\%9A\%D0\%B5\%20\%D0\%B8\%20\%D0\%B7\%D0\%B0\% D1\%88\%D1\%82\%D0\%B8\%D1\%82\%D0\%B0\%20\%D0\%BE\%D0\%B4\%20\%D0\%B4 \%D0\%B8\%D1\%81\%D0\%BA\%D1\%80\%D0\%B8\%D0\%BC\%D0\%B8\%D0\%BD\%D0\% B0\%D1\%86\%D0\%B8\%D1\%98\%D0\%B0.pdf

- National Action Plan for the Implementation of the Law on the Prevention and Protection Against Discrimination 2015-2020. Available at: https://www.mtsp.gov.mk/content/word/NAP\%20for\%20ADL\%2020152020 MK.doc

○ National Equality and Non-Discrimination Strategy 2016-2020. Ministry of Labour and Social Policy. Available at: https://epale.ec.europa.eu/sv/node/160327 and https://www.mtsp.gov.mk/content/pdf/dokumenti/7.7 Strategija\%20za\%20ednakv ost $\% 20 \mathrm{i} \% 20$ nediskriminacija.pdf

○ Nikolovska, M. C. (2020). Discrimination in the Republic of North Macedonia: legal staff, challenges and perception of the basis of discrimination. Available at: https://www.ihr.org.mk/storage/app/media/Publications/Analiza\%20diskriminacij a \%20vo\%20RSM\%202020\%20AL.pdf 
- Office of the Special Advisor on Gender Issues and Advancement of Women. (2001). Gender mainstreaming: Strategy for promoting gender equality. Available at: https://www.un.org/womenwatch/osagi/pdf/factsheet1.pdf

- Risteska, M. Mickovska-Raleva, A. and Lazarevski, G. Perspectives of Women in Rural Areas. Baseline Study of the Status and Livelihoods of Women in Rural Areas and Recommendations for Gender Responsive Policy Responses, CRPM/UN Women, 2011

- Stojanovikj D., Tomikj T., Kunovska V., Vasileva A. (n.d.). Women in rural areas - more obstacles than opportunities, Available at: https://mhc.org.mk/wpcontent/uploads/2019/05/Ruralni Sredini MK 5 .pdf

- State statistical office. (2017). Labour force survey. Available at: https://www.stat.gov.mk/Publikacii/2.4.18.03.pdf

○ State Statistical Office. (n.d.) Available at: https://www.stat.gov.mk/PrikaziSoopstenie.aspx?rbrtxt=98

○ Toronto Centre. (2021). How regulators use sex-disaggregated data and REGTECH to enhance financial inclusion. Available at: https://res.torontocentre.org/guidedocs/TC USAID\%20Main\%20Report\%20FINAL \%20May18.pdf

○ UN women. (n.d.). Available at: https://www.unwomen.org/en/about-us/about-unwomen

$\circ$ UN Women. (n.d.). Convention on the Elimination of All Forms of Discrimination Against Women (CEDAW). Available at: https://www.un.org/womenwatch/daw/cedaw/cedaw.htm

○ UNDP-UN Women, Gender Equality Index for North Macedonia 2019 - Measuring Gender Equality, page 19, available at https://www.mtsp.gov.mk/content/pdf/dokumenti/2019/Gender\%20Index ENG.pdf 